\title{
Ethnobotanical Study of Plant in Historical-Religious Tourism Area and the Sacred Place at Sumenep, Madura
}

\author{
Eva Kristinawati Putri ${ }^{1{ }^{*}}$, Ahmad Bashri ${ }^{1)}$ \\ 1)Biology Department, Faculty of Mathematics and Natural Sciences, Universitas Negeri Surabaya, Jl. Ketintang, \\ Surabaya, East Java, Indonesia \\ *) Correspondence email: evaputri@unesa.ac.id
}

\begin{abstract}
An ethnobotanical study in the Sumenep regency of Madura island has been carried out by observing nine locations, including the historical-religious tourism area and sacred places. This article described plant diversity, use value associated with local knowledge, and socio-cultural value associated with local wisdom. Totally 35 respondents were interviewed consist of primary respondents from each research area and typical respondents. Totally 31 plant species were found in study sites, covering cultivated and socio-cultural plants. Plant diversity was related to role of the location where they took place. Sumenep Palace, the main tourism area located in the center of town, reached the highest diversity of two socio-cultural and 18 cultivated plants as its domestication efforts to attract visitors. Ficus benjamina had the highest socio-cultural values as a usual dwelling for spirits and used to place some offerings, accelerate fortune and specific occasions. The local wisdom of Sumenep people directly related to how these plants can provide benefits, such as Manilkara kauki and Morinda citrifolia which were valuable as socio-cultural plants and fruit trees at once. Ficus benjamina which were valuable as socio-cultural plants related to local wisdom indirectly.
\end{abstract}

Keywords: ethnobotany, conservation, historical tourism area, religious tourism area, the sacred place

\section{Studi Etnobotani Tanaman di Kawasan Wisata Sejarah-Religi dan Tempat Keramat di Sumenep, Madura}

Eva Kristinawati Putri ${ }^{1{ }^{*}}$, Ahmad Bashri ${ }^{1)}$

1)Jurusan Biologi, Fakultas Matematika dan Ilmu Pengetahuan Alam, Universitas Negeri Surabaya, Jl. Ketintang

Gedung C3, Surabaya, Jawa Timur, Indonesia

${ }^{*}$ Alamat korespondensi : evaputri@ unesa.ac.id

\begin{abstract}
ABSTRAK
Studi etnobotani dilakukan pada sembilan lokasi bernilai historis, wisata religi dan keramat di Kabupaten Sumenep, Madura. Artikel ini mendeskripsikan keragaman tumbuhan, kaitan nilai penting dan pengetahuan lokal, serta kaitan nilai sosial budaya dan kearifan lokal. Wawancara dilakukan pada 35 responden yang terdiri dari responden utama di setiap area dan responden umum. Tercatat sejumlah 31 jenis tumbuhan meliputi tumbuhan budidaya dan tumbuhan bernilai sosial budaya. Penelitian ini menunjukkan bahwa keragaman tumbuhan terkait era dengan klasifikasi tempat tumbuhnya. Keraton Sumenep, wisata utama di tengah kota, memiliki keragaman tertinggi. Dua tumbuhan bernilai sosial budaya dan 18 tumbuhan budidaya yang memperindah lokasi tersebut untuk menarik wisatawan. Ficus benjamina memiliki nilai sosial budaya tertinggi yang dipercaya sebagai tempat tinggal makhluk halus, meletakkan sesaji, dipercaya dapat meningkatkan keberuntungan dan tujuan tertentu lainnya. Kearifan lokal masyarakat Sumenep terhadap suatu tumbuhan berkaitan dengan pemanfaatannya secara langsung, seperti Manilkara kauki dan Morinda citrifolia yang bernilai sosial budaya sekaligus dikenal sebagai pohon buahbuahan. Ficus benjamina yang hanya bernilai sosial budaya berkaitan dengan kearifan lokal secara tidak langsung.
\end{abstract}

Kata kunci: etnobotani, konservasi, wisata sejarah, wisata religious, tempat keramat 


\section{INTRODUCTION}

During the last two decades, conservation science is one of the areas that closely related to ethnobiological data [1]. Ethnobiologist should be concerned with plant diversity and its conservation efforts in order to know how a plant does supports the communities among them. Medicinal plants are the most researched topic in ethnobotany followed by edible plants [2]. This study also revealed that ethnobotanical studies related to history are studied infrequently.

Historical, religious and sacred places play an essential role in the ethnobotanical study. Local communities tend to protect these areas and maintained their natural biodiversity as an indirect effort of cultural conservation [3, 4]. Some sacred plants, including the rare ones, were protected in the religious place in India, Tibet, Tanzania and some sacred places throughout the world $[3,4,5,6,7]$. The utilisation and its cultural values are kept over generations.

Sumenep is known for the potency of historical and religious tourism areas, especially as the base entry of Islam into Madura [8]. However, ethnobotanical study for Sumenep considering this potency has never been revealed before. Hence, this research was undertaken in historical-religious tourism areas and sacred places of Sumenep to explore, to make a list of plant diversity, and to describe its importance level with the purposes to give information about use-value, socio-cultural value, including the awareness of further conservation.

\section{METHODS}

Study location. Sumenep is one of four regencies in Madura islands located in East Java, Indonesia $\quad\left(7^{\circ} 1^{\prime} 27.3^{\prime \prime} \mathrm{S}, \quad 113^{\circ} 53^{\prime} 24.74^{\prime \prime} \mathrm{E}\right)$. Sumenep consists of the east part of Madura and some islands such as Talango, Gili Genting, Gili Iyang, Giliraja, Sapudi and some other small islands (Figure 1). We conducted the study in Sumenep city, Kalianget and Talango island which known for the historical and religious tourism area including historical and religious tourism areas and sacred places. Sumenep is the capital city of Sumenep Regency. Kalianget is the eastern part of Madura, which opposite Talango island.

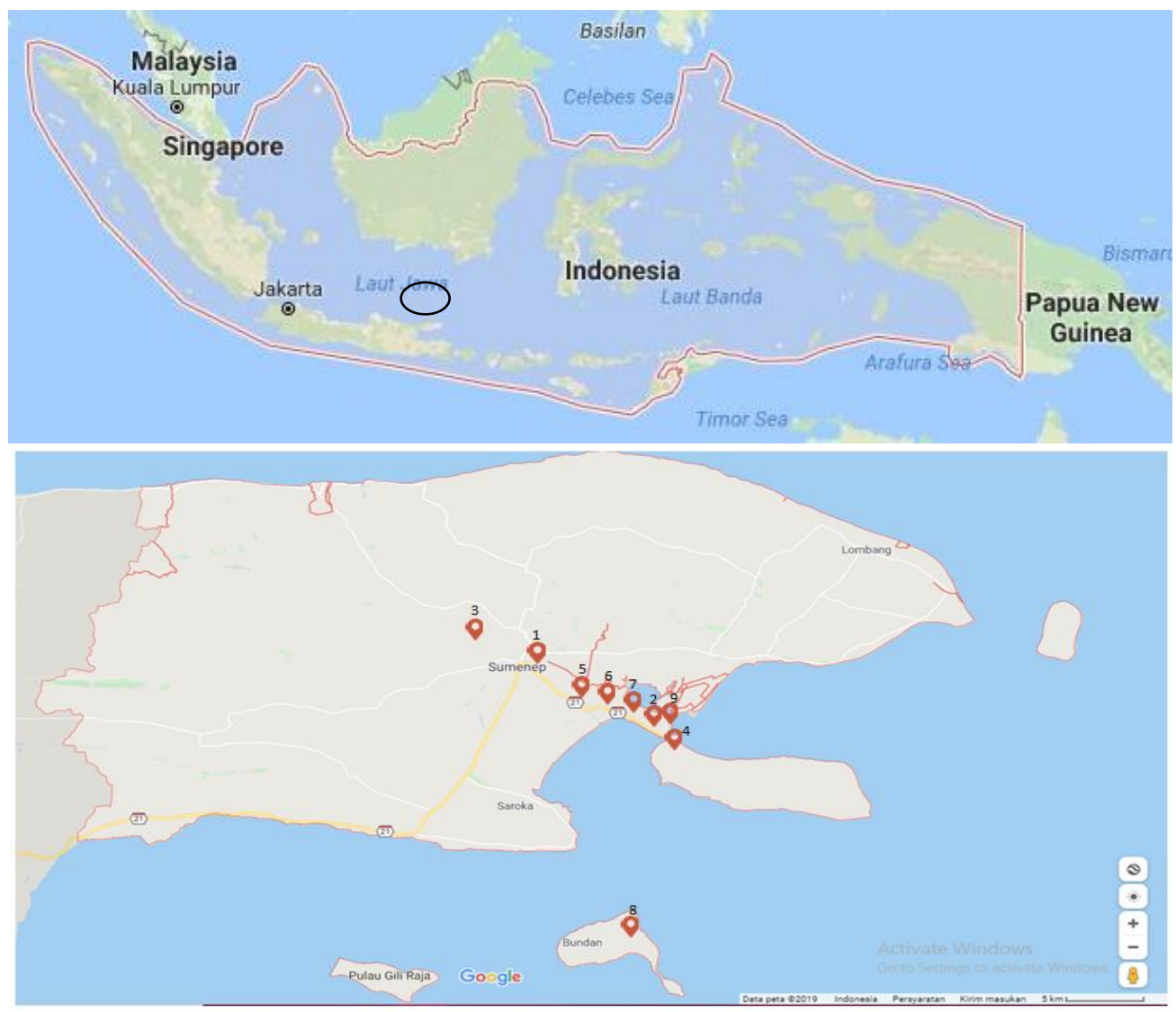

Figure 1. Map of the study area. The numbering order of each area according to Table 1 
Data collections. Historical and religious tourism areas, as well as the sacred places were determined as informed by key respondents selected by both purposive and snowball samplings. The elders or caretakers and local respondents were interviewed for knowing local knowledge and local wisdom. The interview was carried out using open-ended questions. Nine locations were observed, and 34 respondents were interviewed. Documentations including photographs, local name, and herbarium sheets were collected for identification and describe the diversity of plants.

Data Analysis. Plants, especially shrubs and trees, were determined their scientific name at the rank of species and family. These data used to describe plant diversity, plant categorisation, plant distribution, and the relevancy with domestication. The collected data from the interview were transcribed, coded and categorised. The benefits of socio-cultural plants were analysed using use-value. Use-value described how important is a plant in supporting the life of communities by quantifying local knowledge even without using the plant directly [9]. The use-value scored by $\Sigma \mathrm{Ui} / \mathrm{n}$, where $\mathrm{Ui}=$ the number of uses mentioned by the informant for a given species and $n=$ the total number of informants [10]. However, we believe that the level of usage plays a vital role in conservation efforts. Hence, we accessed three additional parameters, namely the level of usage, the level of socio-cultural value, and level of conservation awareness. These parameters counted using the Likert scale ranged from none/do not know till actively contributed (scored by 0-2). The average index was obtained from the total number of scores obtained for each category, then divided by the number of respondents.

\section{RESULTS AND DISCUSSION}

Totally, 31 plant species found in nine observed areas belonging to 30 genera and 21 families. The data presented in a tabular form (Table 1) highlighting their location, local name, scientific name, family, and plant usage. All of these plants have four terms of usage: sociocultural plants, fruit plants, ornamental plants and shading plants. They could be categorised into two groups, namely cultivated and sociocultural plants. Cultivated plants included fruit, ornamental and shading tree. It could be used as an indication of domestication level. Sociocultural plants called for non-cultivated-plants, having spiritual value or myth background and used for specific intentions.

Group 1: cultivated plants. A total of 25 species belonging to 24 genera and 19 families categorised into cultivated plants. Most of this group were ornamental plants, a totally of 11 species belonging to 11 genera and families. They were exclusively planted to beautify and attract more visitors. Fruit plants consist of nine species belonging to eight genera and seven families. Most of them were tropical fruits. Shading plants reached the smallest proportion by five species belonging to five genera and three families. Out of nine observed locations, cultivated plants only found in four locations. Figure 2A showed that Sumenep palace, which categorised as a historical tourism area, reached the most significant number of cultivated plants by a score of $58 \%$. Asta Sayyid Munfar, which categorised as a sacred place, got the smallest by a score of $3 \%$.

Annonaceae, Apocynaceae, Arecaceae, and Fabaceae had the highest representation of cultivated plants (three species each) followed by members of Sapotaceae and Moraceae (two species each), while the remaining 13 families were represented by one species each (Table 1). Plumeria acuminata was the most often seen species seen in three locations, followed by Casuarina equisetifolia, Chrysalidocarpus lutescens, and Manilkara kauki which seen in two locations, while the remaining species were seen in 1 location each.

Table 1 revealed that each species had unspecific usage, even by plant categorisation. For example, Azadirachta indica in Asta Yusuf used as shading plant, but people in Asta Gumuk and Asta Konengan said these species belong to socio-cultural plant. The same case found in Manilkara kauki and M. zapota, which used as fruit plants in some areas but categorised as a socio-cultural plant in another area. Only Lagerstroemia speciosa in Sumenep palace that was believed can be used to getting offspring, while the another tree of this species has no used for this intention (Table 2). This species was known as a male and female tree and had a structure similar to human genitals as the name suggests (Figure 3). The tree if scratched in the "sex" part then boiled with water and drunk believed in providing offspring for the expecting couples. The same species in other places did not have the same efficacy. 
Table 1. Plant list and the usage

\begin{tabular}{|c|c|c|c|c|}
\hline No & Category / Location & Local name & Scientific name (family) & Plant usage \\
\hline $\mathbf{A}$ & \multicolumn{4}{|c|}{ Historical tourism area (purposive sampling) } \\
\hline \multirow[t]{20}{*}{1} & Sumenep Palace & 1. Bungur & Lagerstroemia speciosa (Lythraceae) & socio-cultural plant \\
\hline & & 2. Beringin & Ficus benjamina (Moraceae) & socio-cultural plant \\
\hline & & 3. Mangga & Mangifera indica (Anacardiaceae) & fruit plant \\
\hline & & 4. Belimbing & Averrhoa carambola (Oxalidaceae) & fruit plant \\
\hline & & 5. Sawo kecik & Manilkara kauki (Sapotaceae) & fruit plant \\
\hline & & 6. Sawo manila & Manilkara zapota (Sapotaceae) & fruit plant \\
\hline & & 7. Delima & Punica granatum (Lythraceae) & fruit plant \\
\hline & & 8. Sukun & Artocarpus communis (Moraceae) & fruit plant \\
\hline & & 9. Siwalan & Borassus flabelliber (Moraceae) & fruit plant \\
\hline & & 10. Palem kuning & Chrysalidocarpus lutescencs (Arecaceae) & ornamental plant \\
\hline & & 11. Palem putri & Veitchia merillii (Arecaceae) & ornamental plant \\
\hline & & 12. Sikas & Cycas rumphii (Cycadaceae) & ornamental plant \\
\hline & & 13. Kamboja & Plumeria acuminata (Apocynaceae) & ornamental plant \\
\hline & & $\begin{array}{l}\text { 14. Cemara udang } \\
\text { bonsai }\end{array}$ & Casuarina equisetifolia (Casuarinaceae) & ornamental plant \\
\hline & & 15. Norfolk pine & Araucaria heterophylla (Araucariaceae) & ornamental plant \\
\hline & & 16. Puring & Codiaeum variegatum (Euphorbiaceae) & ornamental plant \\
\hline & & 17. Tabebuya kuning & Tabebuia chrysantha (Bignoniaceae) & ornamental plant \\
\hline & & 18. Glodokan tiang & Polyalthia longifolia (Annonaceae) & ornamental plant \\
\hline & & 19. Bogenvil & Bougainvillea spectabilis (Nyctaginaceae) & ornamental plant \\
\hline & & 20. Dracaena sp. & Dracaena sp. (Asparagaceae) & ornamental plant \\
\hline 2 & $\begin{array}{l}\text { Warehouse complex of } \\
\text { PT Garam Kalianget }\end{array}$ & Trembesi & Albizia saman (Fabaceae) & socio-cultural plant \\
\hline B & \multicolumn{4}{|c|}{ Religious tourism area (purposive sampling) } \\
\hline 3 & Asta Tinggi & Sawo kecik & Manilkara kauki (Sapotaceae) & socio-cultural plant \\
\hline \multirow[t]{5}{*}{4} & \multirow[t]{5}{*}{ Asta Yusuf } & 1. Randu alas & Bombax ceiba (Malvaceae) & socio-cultural plant \\
\hline & & 2. Jambu air & Eugenia aquea (Myrtaceae) & fruit plant \\
\hline & & 3. Kamboja & Plumeria acuminata (Apocynaceae) & ornamental plant \\
\hline & & 4. Mimba & Azadirachta indica(Meliaceae) & shading plant \\
\hline & & 5. Asam & Tamarindus indica (Fabaceae) & shading plant \\
\hline \multirow{11}{*}{$\begin{array}{l}\mathrm{C} \\
5\end{array}$} & \multicolumn{4}{|c|}{ Sacred places(snowball sampling) } \\
\hline & \multirow[t]{10}{*}{ Asta Gumuk } & 1. Mimba & Azadirachta indica(Meliaceae) & socio-cultural plant \\
\hline & & 2. Mengkudu & Morinda citrifolia(Rubiaceae) & socio-cultural plant \\
\hline & & 3. Sawo kecik & Manilkara kauki (Sapotaceae) & fruit plant \\
\hline & & 4. Srikaya & Annona squamosa (Annonaceae) & fruit plant \\
\hline & & 5. Palem kuning & Chrysalidocarpus lutescencs (Arecaceae) & ornamental plant \\
\hline & & 6. Cemara udang & Casuarina equisetifolia (Casuarinaceae) & ornamental plant \\
\hline & & 7. Glodokan tiang & Polyalthia longifolia (Annonaceae) & ornamental plant \\
\hline & & 8. Keres & Muntingia calabura (Muntingiaceae) & shading plant \\
\hline & & 9. Trembesi & Albizia saman (Fabaceae) & shading plant \\
\hline & & 10. Akasia & Acacia sp. (Fabaceae) & shading plant \\
\hline \multirow[t]{4}{*}{6} & \multirow[t]{4}{*}{ Asta Sayyid Munfar } & 1. Sawo manila & Manilkara zapota (Sapotaceae) & socio-cultural plant \\
\hline & & 2. Kalompang & Sterculia foetida(Sterculiaceae) & socio-cultural plant \\
\hline & & 3. Randu alas & Bombax ceiba (Malvaceae) & socio-cultural plant \\
\hline & & 4. Kamboja & Plumeria acuminata (Apocynaceae) & ornamental plant \\
\hline \multirow[t]{2}{*}{7} & The grave of Mbah & Beringin & Ficus benjamina(Moraceae) & socio-cultural plant \\
\hline & Putri RA Anggraini & & & \\
\hline \multirow[t]{2}{*}{8} & Asta Konengan & 1. Mimba & Azadirachta indica(Meliaceae) & socio-cultural plant \\
\hline & & 2. Kosambhi & Schleichera oleosa(Sapindaceae) & socio-cultural plant \\
\hline 9 & Asta Bujuk Kpala & Kalompang & Sterculia foetida(Sterculiaceae) & socio-cultural plant \\
\hline & Perang Raden Mas & & & \\
\hline & Cokro Winoto & & & \\
\hline
\end{tabular}



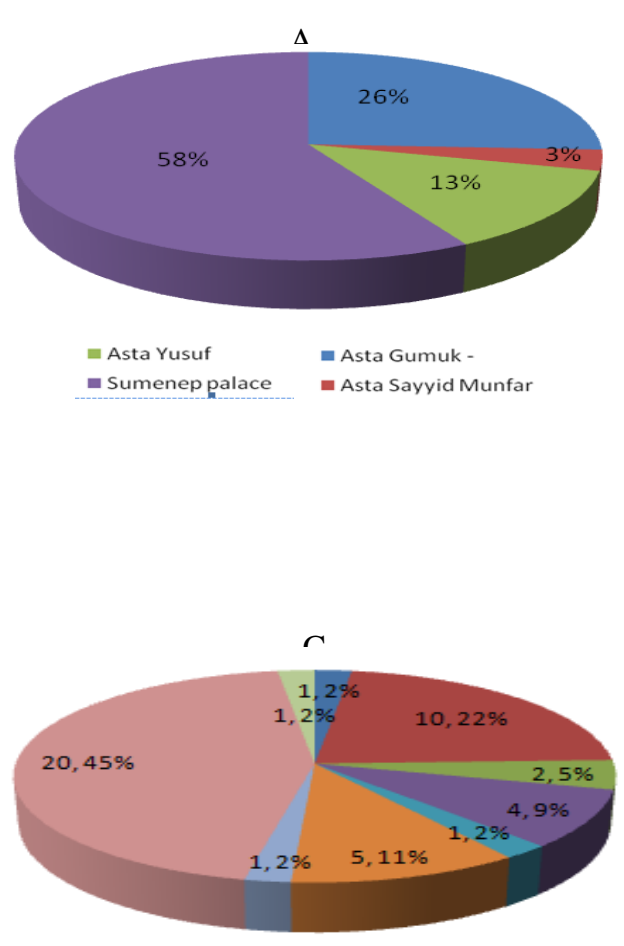

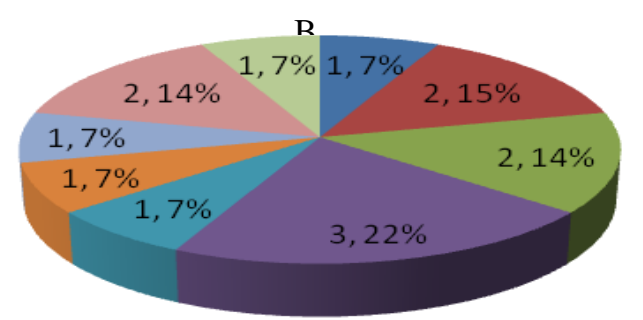

- Asta Tinggi

Esta Yusuf

- Makam Mbah Putri RA Anggrain

= Sumenep Palace

Warehouse complex of PT Garam Kalianget

- Asta Bujuk Kpala Perang Raden Mas Cokro Winoto

- Asta Gumuk

- Asta Konengan

- Asta Sayyid Munfar

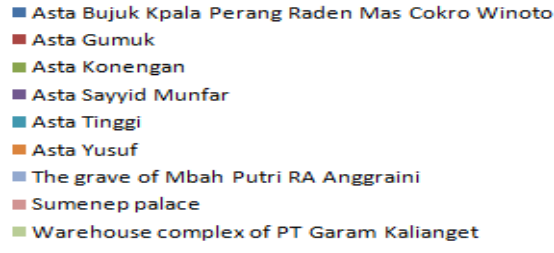

= Warehouse complex of PT Garam Kalianget

Figure 2. Plant proportion. [A] cultivated plants; [B] socio-cultural plants; [C] overall plants

Among three categories of location, Sumenep palace as a historical tourism area reached the highest diversity, especially for cultivated plants. On the contrary, the sacred place has less plant diversity, which is dominated by socio-cultural plants.

Sumenep palace has two socio-cultural plants and 18 cultivated plants. The ratio indicated the efforts of domestication related to its position as the main tourist object in Sumenep. Its location in the city center made this place easy to reach by domestic and foreign tourists. Cultivated plants were beautifully designed to attract more visitors. Plant diversity is one of the biggest assets that can interest tourist [11]. It can make tourist feel a relaxed atmosphere, especially for the tourist that usually live by buildings towering among them [12].

Group 2 socio-cultural plants. A total of ten species belonging to nine genera and nine families categorized into socio-cultural plants. Asta Sayyid Munfar, which categorised as a sacred place, reached the highest percentage of socio-cultural representation by a score of $3.22 \%$ followed by Asta Gumuk, Asta Konengan and Sumenep palace by a score of $2.14 \%$, while the remaining locations were represented by $1.7 \%$ (Figure 2B). Azadirachta indica, Bombax ceiba, Ficus benjamina, and
Sterculia foetida found in two areas as a sociocultural plant. Sapotaceae had two species of socio-cultural plant, and they were Manilkara kauki and M. zapota.

Figure $2 \mathrm{C}$ showed the percentage of all plant categories for each location. Sumenep Palace, one of the historical tourism area, got the highest diversity by a score of $20.45 \%$ (20 species). Asta Gumuk, one of a sacred place, got the second rank by a score of $10.22 \%$ (10 species), a half percentage from Sumenep palace.

As per belief, socio-cultural plants were considered as a sacred tree, having some natural power or related to some myth background (Table 2). Ficus benjamina and Bombax ceiba reached the highest use-value including usual benefit and socio-culture value.

Table 3 showed that Manilkara kauki and Morindacitrifolia got the highest level of conservation awareness, by a score of 2 and 1.5 , respectively. Both of them have a relatively high average index, not only for the level of sociocultural value $(0.5)$ but also for the level of usage (1.75 and 1.5, respectively). They could be used as fruit plants or medicinal plants. Moreover, this plant does not require large areas under cultivation. Therefore, respondents said that they agreed to make the effort reproduction or preservation if given the seed of these plants. 
Table 2. Benefits and use-value of socio-cultural plants.

\begin{tabular}{|c|c|c|c|c|c|}
\hline No & $\begin{array}{l}\text { Scientific Names } \\
\text { (Family) }\end{array}$ & Location & Socio-cultural value & Benefit & $\begin{array}{l}\text { Use Value } \\
(n=35)\end{array}$ \\
\hline 1 & $\begin{array}{l}\text { Lagerstroemia speciosa } \\
\text { (Lythraceae) }\end{array}$ & $\begin{array}{l}\text { Sumenep } \\
\text { palace }\end{array}$ & $\begin{array}{l}\text { Getting offspring by touching } \\
\text { or shaving-drinking the } \\
\text { "genital" part }\end{array}$ & Fertility medicine & 0.4 \\
\hline 2 & $\begin{array}{l}\text { Ficus benjamina } \\
\text { (Moraceae) }\end{array}$ & $\begin{array}{l}\text { Sumenep } \\
\text { palace } \\
\text { The grave of } \\
\text { Mbah Putri RA } \\
\text { Anggraini }\end{array}$ & $\begin{array}{l}\text { Dwelling for spirits, specific } \\
\text { rituals and possessed for } \\
\text { pruning } \\
\text { Dwelling for spirits, strange } \\
\text { disease because of pruning } \\
\text { without permission to the } \\
\text { dwelling }\end{array}$ & $\begin{array}{l}\text { - Laid offerings } \\
\text { - Putting } \\
\text { money/invoke } \\
\text { fortune } \\
\text { - Invoke blessing for } \\
\text { the specific intent } \\
\text { - Shading tree }\end{array}$ & 3.87 \\
\hline 3 & $\begin{array}{l}\text { Bombax ceiba } \\
\text { (Malvaceae) }\end{array}$ & $\begin{array}{l}\text { Asta Sayyid } \\
\text { Munfar }\end{array}$ & $\begin{array}{l}\text { Considered as the cammock of } \\
\text { Sayyid Munfar. It is believed } \\
\text { having undrawn treasures } \\
\text { Considered as the cammock of } \\
\text { Sultan Abdurrahman, the place } \\
\text { to invoke agate and hermitage }\end{array}$ & $\begin{array}{l}\text { - Season turnover } \\
\text { markers } \\
\text { - Laid offerings } \\
\text { - Points penance } \\
\text { - Leaves and stems } \\
\text { for medicinal }\end{array}$ & 3,8 \\
\hline 4 & $\begin{array}{l}\text { Samanea saman } \\
\text { (Fabaceae) }\end{array}$ & $\begin{array}{l}\text { Warehouse } \\
\text { complex of PT } \\
\text { Garam } \\
\text { Kalianget }\end{array}$ & $\begin{array}{l}\text { Sacred tree, believed as the } \\
\text { hecatomb place of thousands of } \\
\text { Dutch slave, dwelling for } \\
\text { spirits namely genderuwo }\end{array}$ & $\begin{array}{l}\text { Not used } \\
\text { (sacred) }\end{array}$ & 0 \\
\hline 5 & $\begin{array}{l}\text { Manilkara kauki } \\
\text { (Sapotaceae) }\end{array}$ & Asta Tinggi & $\begin{array}{l}\text { Considered as a plant that is } \\
\text { planted by the elders of } \\
\text { Sumenep Kingdom }\end{array}$ & $\begin{array}{l}\text { - fruit consumed } \\
\text { - leaves for } \\
\text { medicinal } \\
\text { - twigs for fuel }\end{array}$ & 1,4 \\
\hline 6 & $\begin{array}{l}\text { Manilkara zapota } \\
\text { (Sapotaceae) }\end{array}$ & $\begin{array}{l}\text { Asta Sayyid } \\
\text { Munfar }\end{array}$ & $\begin{array}{l}\text { Sacred tree, possessed for } \\
\text { taking fruit or twig without } \\
\text { permission to the dwelling, } \\
\text { having undrawn treasures, } \\
\text { place for tirakat (fasting for } \\
\text { specific intent) }\end{array}$ & $\begin{array}{l}\text { - shading tree } \\
\text { - Laid offerings } \\
\text { - Tirakat/specific } \\
\text { intent }\end{array}$ & 0.7 \\
\hline 7 & $\begin{array}{l}\text { Azadirachta indica } \\
\text { (Meliaceae) }\end{array}$ & $\begin{array}{l}\text { Asta Gumuk } \\
\text { Asta Konengan }\end{array}$ & $\begin{array}{l}\text { Sacred tree, causing an accident } \\
\text { because not greetings to the } \\
\text { dwelling } \\
\text { Sacred tree, laid offering a } \\
\text { place for a specific intent, } \\
\text { causing possessed for taking } \\
\text { leaves without permission }\end{array}$ & $\begin{array}{l}\text { - Shading tree } \\
\text { - Blood neutralizer } \\
\text { - Medicine for } \\
\text { cholesterol } \\
\text { - Drugs for itching } \\
\text { - Laid offerings }\end{array}$ & 2,2 \\
\hline 8 & $\begin{array}{l}\text { Schleichera oleosa } \\
\text { (Sapindaceae) }\end{array}$ & Asta Konengan & $\begin{array}{l}\text { Sacred tree, place for tirakat, } \\
\text { being the place of undrawn } \\
\text { Konengan kris, causing curse } \\
\text { shown by convulsions and } \\
\text { fever }\end{array}$ & $\begin{array}{l}\text { - Laid offerings } \\
\text { - Tirakat/specific } \\
\text { intent }\end{array}$ & 0,8 \\
\hline 9 & $\begin{array}{l}\text { Morinda citrifolia } \\
\text { (Rubiaceae) }\end{array}$ & Asta Gumuk & $\begin{array}{l}\text { Sacred tree, causing an accident } \\
\text { because not greetings to the } \\
\text { dwelling }\end{array}$ & $\begin{array}{l}\text { - Shading tree } \\
\text { - Medicine for cough }\end{array}$ & 1 \\
\hline 10 & $\begin{array}{l}\text { Sterculia foetida } \\
\text { (Sterculiaceae) }\end{array}$ & $\begin{array}{l}\text { Asta Bujuk } \\
\text { Kpala Perang } \\
\text { Raden Mas } \\
\text { Cokro Winoto } \\
\text { Asta Sayyid } \\
\text { Munfar } \\
\end{array}$ & $\begin{array}{l}\text { Sacred tree, a place for tirakat, } \\
\text { laid offerings }\end{array}$ & $\begin{array}{l}\text { - Laid offerings } \\
\text { - Medicine for } \\
\text { giving birth woman } \\
\text { - Animal feed }\end{array}$ & 2.67 \\
\hline
\end{tabular}

On the contrary, Ficus benjamina got the highest score of socio-cultural value by score of 1 , far beyond other plants that only reached a score of $0.25-0.5$. This plant was tightly attached eerie impression of being dwellings for spirits. In addition, it required extensive land for crops. Therefore, the level of conservation awareness of this plant only reached 1 . Respondents thought that $F$. benjamina need to be preserved without a real action to cultivate. The preservation of these plants in their natural habitat was more likely because people did not dare disturb its existence because of fear of spirits disturbance. 
Table 3. The average index

\begin{tabular}{|c|c|c|c|c|}
\hline \multirow[b]{2}{*}{ No. } & \multirow[b]{2}{*}{ Plants } & \multicolumn{3}{|c|}{ Average index $(n=35)$} \\
\hline & & Level of usage & $\begin{array}{l}\text { Level of socio- } \\
\text { cultural value }\end{array}$ & $\begin{array}{l}\text { Level of } \\
\text { conservation } \\
\text { awareness }\end{array}$ \\
\hline 1 & Lagerstroemia speciosa & 0.25 & 0.25 & 1 \\
\hline 2 & Ficus benjamina & 1 & 1 & 1 \\
\hline 3 & Bombax ceiba & 0.8 & 0.4 & 1 \\
\hline 4 & Samanea saman & 0 & 0.25 & 0.5 \\
\hline 5 & Manilkara kauki & 1.75 & 0.5 & 2 \\
\hline 6 & Manilkara zapota & 0,5 & 0.25 & 1 \\
\hline 7 & Azadirachta indica & 1.125 & 0.5 & 1 \\
\hline 8 & Schleichera oleosa & 1.25 & 0.25 & 0.75 \\
\hline 9 & Morinda citrifolia & 1.5 & 0.5 & 1.5 \\
\hline 10 & Sterculia foetida & 0.57 & 0.29 & 1 \\
\hline
\end{tabular}

The level of conservation awareness of Samanea saman was the lowest (0.5). It had socio-cultural values $(0.25)$ but respondents did not take advantage of this tree. The first reason was because of its location in the warehouse PT Garam which the fence was always locked. The second reason was this plant had the impression austere as the bodies of thousands of indigenous workers stacked without a proper burial by the invaders.

The socio-cultural plant had special value to the community, either believed to its spiritual value or believed to cure certain diseases. Some plants, which were believed to cure certain diseases, were a species found explicitly at the sites. For example, Azadirachta indica at Asta Gumuk and Asta Konengan had the benefit of laid offerings. This species also found as a shaded plant without any socio-cultural value.

The age of the tree usually related to the culture, traditions and myths they had [13]. The old culture, traditions and myths usually owned by the older tree. They were passed down to the next generation. Three socio-cultural plants with the highest use-value were the old Ficus benjamina, Bombax ceiba, and Sterculia foetida respectively. These use values were related to the age of the plant.

Ficus benjamina in Sumenep Palace and the grave of Mbah Putri RA Anggraeni ordinary visited by people who will open a business. Because it was believed to facilitate the fortune and who will have particular intent due believed to make the event run smoothly. It also was used to put the cone or offerings at certain moments, for example, was pruning times (Figure 3). F. benjamina was considered sacred because of inhabitants of some spirits. If pruning was done without the permission or put offerings first, then the inhabitants would be angry and unwanted things happen. Trimming the $F$. benjamina in Sumenep Palace without putting offerings was reported to have resulted in a trance, while at the grave of Mbah Putri RA Anggraini reported has resulted in making the trimmer injured in hand and a high fever that cannot be cured by a doctor until nearly died. $F$. benjamina was known as a socio-cultural plant in different areas. Tengger ethnic usually used this species as one of the material for staple offerings in Kasada ceremony [14]. This plant also used in Banjar ethnic, not only for some rituals for the wealth of communities but also for the materials used to supernatural power [15].

Besides being used as a medicine, Bombax ceiba had a socio-cultural value to the people of Sumenep. Cotton tree was believed to be the incarnation of stick or a certain figure: Sultan Abdurrahman at Asta Yusuf and the cammock of Sayyid Munfar at Asta Sayyid Munfar (Figure 4). Cotton tree was also reported to have a socio-cultural value for the Indian community, especially during the festival of Holi [13]. 


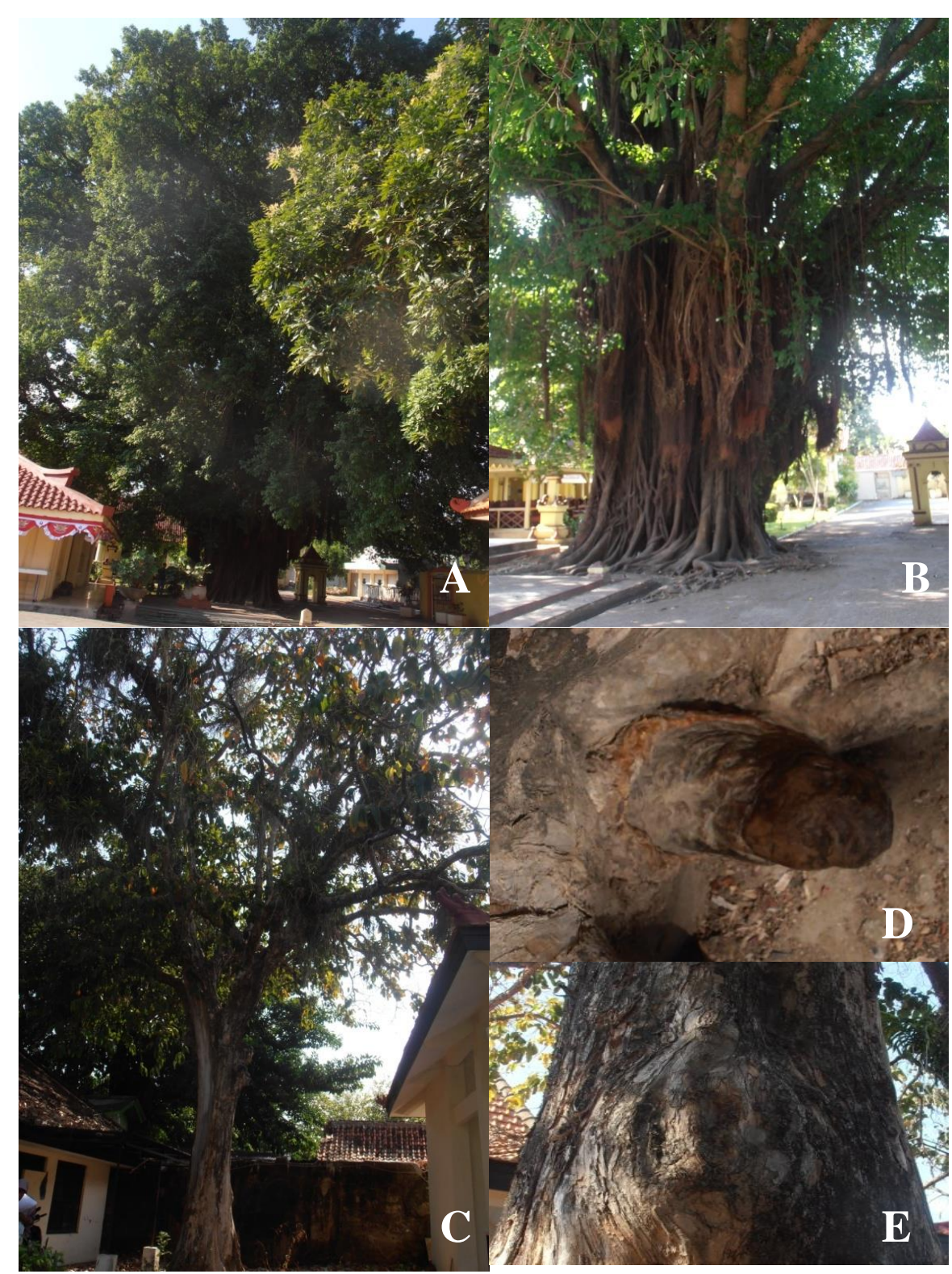

Figure 3. Socio-cultural plants in Sumenep Palace. [A-B] Ficus benjamina; [C-E] Lagerstroemia speciosa; [C] habitus; [D] "male" genital of male tree; [E] "female" genital of female tree.

Tamarind was a plant with a socio-cultural value that did not have use-value. This was related to the location in the complex PT Gudang Garam Kalianget. This tree was believed to be buried where native workers when the Dutch colonial period in bulk with no feasible way, that his body was just dumped granted. This tree was considered sacred and eerie so that no one dared to cut them down. This tree was located in a complex with iron gates were locked so that the public is also tricky if they want to use it.

People tended to do multiplication or conservation efforts on plants that were perceived to provide more benefits. Some respondents said that they had actively contributed to the conservation by cultivating some species at their house. If given some seeds, respondents said that they want actively contribute more by cultivating some plants that give them more benefit and does not require large areas under cultivation. Cultivating could explain the direct local wisdom of communities.

Moreover, the local wisdom of communities could be explained indirectly from the case of a socio-cultural plant, for example, Ficus benjamina. Respondents complained that they had to contribute on to the cultivation actively. On the other hand, they are afraid to disturb the old $F$. benjamina because of the dwelling spirits. It also used for some specific occasions. In this case, $F$. benjaminawith socio- 


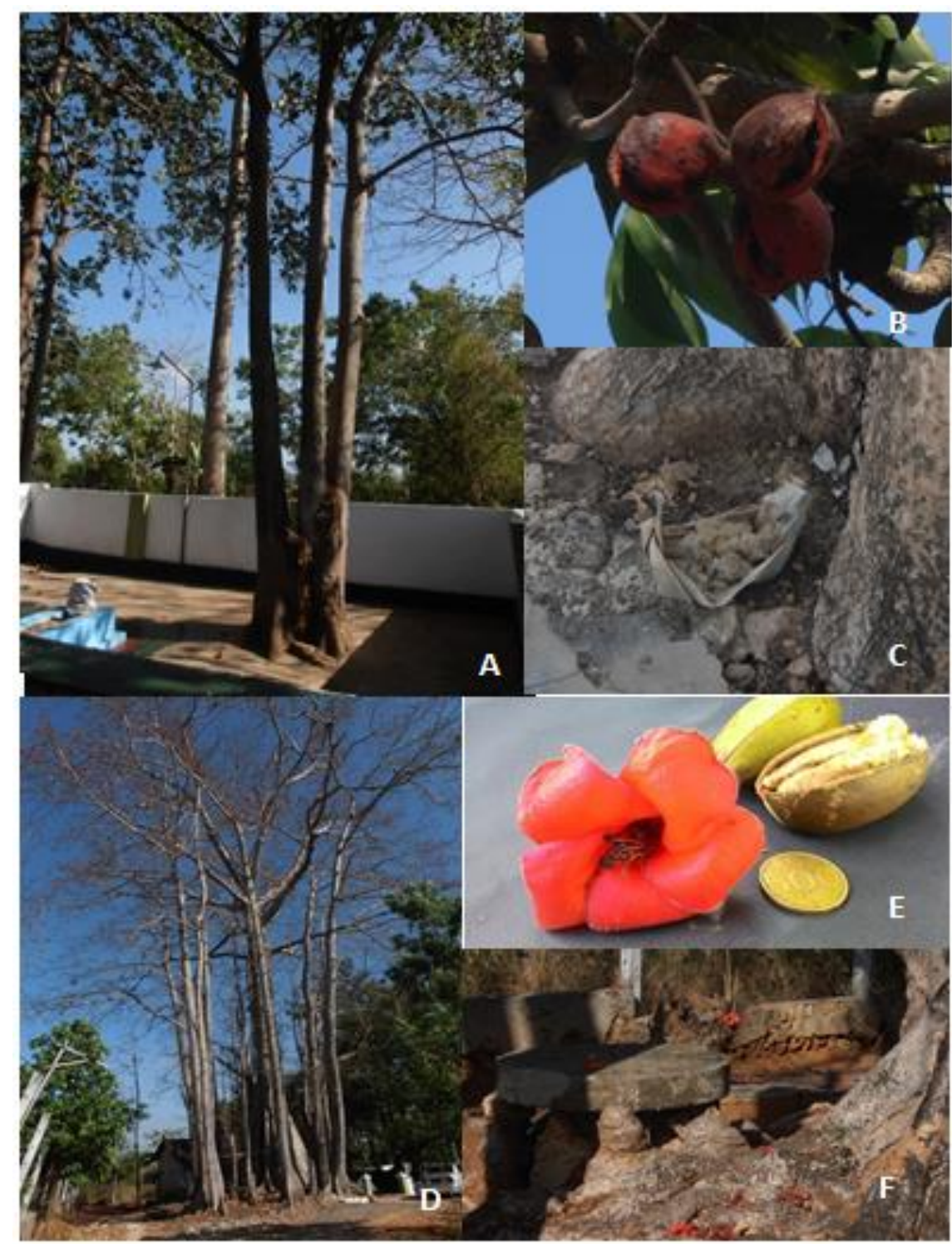

Figure 4. Socio-cultural plants of Asta Sayyid Munfar. [A-C] Sterculia foetida; [A] habitus; [B] fruit; [C] offerings; [D-F] Bombax ceiba; [D] habitus; [E] flower and fruit; [F] table and chairs for tirakat.

cultural value would exist for a long time. Thus, it is clear that religious beliefs have a role in protecting the environment and flora as their elements [4].

\section{CONCLUSION}

Plant diversity of the historical and religious tourism areas and sacred places in Sumenep was quite high, with a total of 31 species by the detail of ten socio-cultural plants and 21 cultivated plants. The highest plant diversity in Sumenep Palace indicated some domestication efforts to attract tourists. Ficus benjamina had the highest socio-cultural values that were considered sacred because of the usual dwelling of spirits and so were used to place put offerings, accelerate fortune, and specific intent. Local wisdom Sumenep was directly related to how these plants could provide benefits, such as Manilkara kauki and Morinda citrifolia both as a socio-cultural and cultivated plant. Indirect local wisdom, for example, was the sacred $F$. benjamina.

\section{REFERENCES}

[1] Wolverton S (2013) Ethnobiology 5: Interdisciplinarity in an era of rapid environmental change. Ethnobiology Letters 4: 21-25.

[2] Hakim L (2014) Etnobotani dan Manajemen Kebun-Pekarangan Rumah: Ketahanan Pangan, Kesehatan dan 
Agrowisata, Selaras, Malang.

[3] Turner NJ, Ari Y, Berkes F, Davidson-hunt I, Ertug F, Miller, A (2009) Cultural management of living trees: An international perspective. Journal of Ethnobiology 29(2): 237-270.

[4] Mohanty R, Tripathy BK, Panda T (2012) Role of temples and other holy places in plant conservation of Odisha, India. International Journal of Conservation Science 3(4): 301-308.

[5] Msuya TS, Kideghesho JR. (2009) The role of traditional management practices in enhancing sustainable use and conservation of medicinal plants in West Usambara Mountains. Tropical Conservation Science 2(1): 88-105.

[6] Shen X, Lu Z, Li S, Chen N (2012) Tibetan sacred sites: Understanding the Traditional Management. Ecology and Society 17(2): 13.

[7] Hidayati S, Franco FM, Bussmann RW (2015) Ready for phase 5 - Current status of ethnobiology in Southeast Asia. Journal of Ethnobiology and Ethnomedicine 11:17. doi: 10.1186/s13002-015-0005-7.

[8] Sodik A (1997) Dakwah islamiyah di Sumenep: Studi sejarah dakwah Sunan Padusan di Kraton Sumenep abad ke-15: Unpublished thesis.

[9] de Albuquerque UP (2006) Re-examining hypotheses concerning the use and knowledge of medicinal plants: a Study in the Caatinga Vegetation of NE Brazil. Journal of Ethnobiology and Ethnomedicine 2: 30. doi: 10.1186/17464269-2-30.

[10] Rossato SC, Leitão-Filho HF, Begossi A (1999) Ethnobotany of Caiçaras of the Atlantic Forest coast (Brazil). Econ bot 53:387-395.

[11] Buckley R, Pickering C, Weaver DB (2003) Nature-Based Tourism, Environment, and Land Management. Wallingford, UK. CABI

[12] Boz D (2014) Diversification of botanic tourism by benefiting from the plantbioinformatics system. Global Review of Research in Tourism, Hospitality and Leisure Management 1(2): 102-116.
[13] Jain V, Verma S, Katewa S (2009) Myths, traditions, and fate of multipurpose Bombax ceiba L. Indian Journal of Traditional Knowledge 8(4): 638-644.

[14] Pramita NH, Indriyani S, Hakim L (2013) Etnobotani Upacara Kasada Masyarakat Tengger, di Desa Ngadas, Kecamatan Poncokusumo, Kabupaten Malang. Journal of Indonesian Tourism and Development Studies 1(2): 52-61.

[15] Anggana AF (2011) Kajian etnobotani masyarakat di sekitar Taman Nasional Gunung Merapi: Studi kasus di Desa Umbulharjo, Sidorejo, Wonodoyo dan Ngablak. Thesis, Institut Pertanian Bogor. 